MARCIN BRONIARCZYK*

Muzeum Ziemi Rawskiej

ORCID: 0000-0002-5405-5918

\title{
AKTYWNOŚĆ SENATORÓW Z WOJEWÓDZTWA RAWSKIEGO NA SEJMACH DOBY WAZÓW (1587-1668)
}

\author{
Activity of Senators of the Rawa Voivodship during the Sejms \\ of the Vasas' times (1587-1668) \\ Abstract
}

The article discusses the activity of senators of the Rawa Voivodship in the Sejms during the reign of three consecutive Vasas (1587-1668). It depicts the most active Senators, presenting their political biographies and a brief overview of their civil servants' career and sources of senatorial promotion. The focus is mainly on participation in Sejms and various forms of parliamentary activity such as: participation in debates, speaking in the Senate as well as participation in various committees and deputations, for which they were appointed in Sejms. The attached table lists all senators from the discussed period according to the hierarchy of offices and in a chronological order, noting their presence in a given Sejm.

Keywords: Senate, the Vasas, Rawa Voivodship, voivode, castellan

\begin{abstract}
Abstrakt
W artykule omówiona została aktywność senatorów z województwa rawskiego na sejmach za panowania trzech kolejnych Wazów (1587-1668). Zaprezentowano sylwetki kilku najbardziej aktywnych senatorów, prezentując ich życiorysy polityczne. Przedstawiono w skrócie przebieg ich kariery urzędniczej i źródła awansu senatorskiego. Skupiono się głównie na uczestnictwie w sejmach i różnych formach aktywności parlamentarnej takich jak: udział w obradach, zabieranie głosu podczas wotów senatorskich, a także uczestnictwo w różnego rodzaju komisjach i deputacjach, do których byli wyznaczani na sejmach. W załączonej tabeli zestawiono wszystkich senatorów z omawianego okresu według hierarchii urzędów i w porządku chronologicznym, odnotowując ich obecność na poszczególnych sejmach.
\end{abstract}

Słowa kluczowe: senat, Wazowie, województwo rawskie, wojewoda, kasztelan

\footnotetext{
* Dr Marcin Broniarczyk - dyrektor Muzeum Ziemi Rawskiej w Rawie Mazowieckiej; zainteresowania: staropolski parlamentaryzm, dzieje rodzin szlacheckich z Wielkopolski, Kujaw i Mazowsza w XVI-XVII w., historia oświaty i wychowania w okresie przedrozbiorowym; kontakt: marcin.broniarczyk85@gmail.com.
} 
W omawianym okresie województwo rawskie było reprezentowane w senacie przez czterech senatorów: wojewodę rawskiego; kasztelana rawskiego oraz kasztelanów: sochaczewskiego i gostynińskiego. W czasach Wazów urząd wojewody rawskiego pełniło 12 senatorów; kasztelanów rawskich było 11; kasztelanów sochaczewskich 12 zaś kasztelanów gostynińskich - 7; co łącznie daje 42 urzędników. Nie bez powodu podkreślam, że mowa tu o urzędnikach/ senatorach w sensie formalnym, gdyż osób pełniących te funkcje było mniej. Wynikało to $\mathrm{z}$ racji awansów i pełnienia przez niektóre z tych osób kilku urzędów senatorskich w województwie rawskim. Takich osób było sześć: Stanisław Gostomski kasztelan sochaczewski (1572-1588), a następnie wojewoda rawski (1588-1595); Hieronim Parys kasztelan sochaczewski (1589-1592), później kasztelan rawski (1592-1596); Stanisław Radziejowski kasztelan rawski (1611-1618), a następnie wojewoda rawski (1618-1628); Filip Wołucki kasztelan rawski (1619-1628), później wojewoda rawski (1628-1642); wreszcie rodzeni bracia: Franciszek Feliks Lipski kasztelan sochaczewski (1631-1639), następnie kasztelan rawski (1639-1643), i Kasper Zygmunt Lipski kolejno: kasztelan sochaczewski (1639-1643), kasztelan rawski (1643-1654) i u schyłku życia wojewoda rawski (1654-1656). Nie sposób w tak krótkim szkicu omówić szczegółowo działalności wszystkich interesujących mnie senatorów tego okresu. Dlatego też zasadniczo skupię swoją uwagę na wymienionych powyżej, pełniących po kilka urzędów senatorskich w województwie oraz najbardziej aktywnych na forum publicznym ${ }^{1}$.

Zacznę od Stanisława Gostomskiego h. Nałęcz. Był on najstarszym synem Anzelma, wojewody rawskiego, i jego pierwszej żony Narzymskiej. Karierę zaczynał jeszcze za Zygmunta Augusta. Posłował na sejmy, w 1567 r. z sejmiku płockiego w Raciążu, zaś w 1570 r. z sejmiku chełmskiego. W 1572 r. wszedł do senatu za sprawą nominacji na kasztelanię sochaczewską. Przejawiał dużą aktywność w czasie drugiej elekcji, kiedy to należał do zagorzałych zwolenników Habsburga. Był już wówczas starostą rawskim. Miało to istotne znaczenie, gdyż jako szafarz skarbu rawskiego miał do niego bieżący dostęp i - wykorzystując te środki - wsparł zwolenników cesarza Maksymiliana II. Ostatecznie jednak - po śmierci cesarza - opowiedział się za kandydaturą Stefana Batorego. Za panowania tego władcy należał do wiernych stronników kanclerza Jana Zamoyskiego i aktywnych senatorów. Był

\footnotetext{
1 Problematyka ta jak dotychczas była przedmiotem zainteresowania Michała Kobiereckiego, który przyjrzał się działalności całej zbiorowości parlamentarzystów rawskich w omawianym okresie, a zatem zarówno senatorów jak i posłów. Zob. M. Kobierecki, Aktywność parlamentarzystów rawskich na sejmach za panowania Wazów 1587-1668, „Przegląd Nauk Historycznych”, 5/2006, nr 1(9), s. 75-107. W niniejszym tekście uzupełniono wiele informacji na temat poszczególnych senatorów w oparciu o nowo pozyskane źródła i najnowszą literaturę przedmiotu, a niekiedy skorygowano omyłkowe twierdzenia autora. W dużej mierze opierałem się na własnych ustaleniach zawartych w: M. Broniarczyk, Kasztelanowie mniejsi z Wielkopolski, Kujaw i Mazowsza w czasach Władysława IV, praca doktorska napisana pod kierunkiem prof. dr. hab. Edwarda Opalińskiego, Warszawa 2015, maszynopis w Bibliotece IH PAN w Warszawie; idem, Kasztelanowie rawscy doby Wazów (1587-1668), [w druku]; idem, Kilka uwag o edukacji rawskiej elity politycznej w XVII w. na przykładzie Lipskich h. Łada, w: Najjaśniejsza Rzeczypospolita. Studia ofiarowane Profesorowi Andrzejowi Stroynowskiemu, red. M. Durbas, Częstochowa 2019, s. 599-607. Od czasu publikacji artykułu Kobiereckiego ukazało się szereg prac, które umożliwiły pogłębione studia nad tym zagadnieniem. Przede wszystkim mam tu na myśli wydane drukiem lauda rawskie oraz prace Andrzeja Korytki i Leszka Wierzbickiego, w których można znaleźć sporo informacji na temat udziału senatorów rawskich w pracach sejmowych w omawianym okresie. Por. Lauda ziemi rawskiej i województwa rawskiego 1583-1793, oprac. M. Bąk, M. Borkowski, K. Chłapowski, A. Haratym, T. Płóciennik, Ł. Przybyłek, E. Walczuk, red. M. Nagielski, Warszawa 2017 (tu także pierwsze kompletne zestawienie senatorów rawskich, na którym zasadniczo oparty jest aneks do niniejszego tekstu); A. Korytko, , Na których opiera się Rzeczpospolita”. Senatorowie koronni za Władysława IV Wazy, Olsztyn 2015; L. A. Wierzbicki, Senatorowie koronni na sejmach Rzeczypospolitej w XVII wieku, Warszawa 2017.
} 
obecny na sejmach w latach $1578,1579 / 1580,1581,1582,1585^{2}$. Na elekcji w 1587 r. poparł kandydaturę Zygmunta Wazy, którego - po przybyciu do Polski - eskortował z własnym oddziałem jazdy z Gdańska do Krakowa. W dalszym ciągu pozostawał starostą rawskim i dysponował skarbem kwarcianym, który tym razem przekazał do dyspozycji Janowi Zamoyskiemu, czym również dopomógł w elekcji Jagiellona po kądzieli. Był obecny na sejmie koronacyjnym (1587/88). Podczas jednej z sesji pojawiła się kwestia upływającego terminu wypłaty żołdu i związana z tym konieczność podjęcia negocjacji z wojskiem. Autor diariusza zanotował, że postanowiono: „Posłać li do wojska kogo, coby z żołnierzami traktował i służbę dalszą przypowiedzieć. Mianowali pana sochaczewskiego, wymówił się: «Nie będę Rzptej służył, bo mi nic nie dają, a też ja tam nie pojadę, żeby dać po 30 złotych za ćwierć. Widzę to być wielką szkodę Rzptej i niepodobną rzecz, abyśmy ten żołd zapłacić mogli»»"3. Później Gostomski uczestniczył jeszcze w sejmach: 1589, 1590 (wotował), 1591/92 (wotował), 1592 (wotował), 1593, 1595 (wotował).

Hieronim Parys h. Prawdzic był synem Feliksa, kasztelana warszawskiego i Katarzyny Brochowskiej ${ }^{4}$. Na forum publicznym pojawia się po raz pierwszy w 1576 r., na sejmiku czerskim. Przyjeżdżał także na obrady sejmiku sochaczewskiego (1592). Najpewniej jeszcze od Stefana Batorego otrzymał kasztelanię warszawską, gdyż w tym charakterze występował na sejmie konwokacyjnym w 1587 r. W czasie trzeciej elekcji początkowo opowiadał się za Habsburgiem. Ostatecznie jednak zagłosował za elekcją Zygmunta Wazy. O tym, że decyzja ta była trafna, świadczył awans, już w 1589 r., na kasztelanię sochaczewską. Kasztelanem rawskim został w 1592 r. Ukoronowaniem jego kariery był urząd wojewody mazowieckiego, który otrzymał w 1596 r. $^{5}$ Interesowały go sprawy publiczne. Na sejmie w 1597 r. domagał się powołania komisji dla postanowienia obrony kraju. Awans wielkosenatorski najwyraźniej rozbudził w nim ambicje odgrywania czołowej roli w województwie. Na przedsejmowym sejmiku czerskim w 1598 roku popadł w konflikt z miejscową szlachtą, nie chcąc dopuścić do obioru marszałka. Zmarł w 1605 r. ${ }^{6}$

Stanisław Radziejowski h. Junosza pochodził z mazowieckiej rodziny, której gniazdem rodowym były Radziejowice w ziemi sochaczewskiej. W 1599 r. otrzymał nominację na pierwszy urząd - starosty sochaczewskiego. W 1600 r. zadebiutował jako poseł na sejm z sejmiku sochaczewskiego. W 1603 r. na sejmiku sochaczewskim przyczynił się do tumultu zakończonego rozlewem krwi. Był to efekt ostrego konfliktu o obsadę urzędu podkomorzego sochaczewskiego, który toczył z rodziną Trzcińskich. W potyczce, do której doszło w kościele, ludzie Radziejowskiego zabili kilkoro szlachty, co mogło przysporzyć mu poważnych problemów. Ostatecznie jednak konflikt został zażegnany. Najprawdopodobniej pomogła mu w tym protekcja kanclerza Jana Zamoyskiego, zaś sam Radziejowski ponownie uzyskał mandat posła na sejm z Sochaczewa ${ }^{7}$. W czasie rokoszu Zebrzydowskiego pozostawał

\footnotetext{
2 Szerzej na temat działalności S. Gostomskiego przed 1587 r. zob.: L. Kieniewicz, Senat za Stefana Batorego, Warszawa 2000, passim; Laudum sejmiku województw sandomierskiego i lubelskiego w Opatowie 15 grudnia 1577 r., w: Akta sejmikowe województwa lubelskiego 1572-1632, oprac. H. Gmiterek, Lublin 2016, s. 42; K. Lepszy, Gostomski Stanisław z Leżenic, w: Polski Stownik Biograficzny (dalej: PSB), t. 8, Wrocław 1959-1960, s. 367-369; Ł. Wroniszewski, Elity szlacheckie na sejmie - frekwencja senatorska na sejmach Stefana Batorego (1576-1586), w: Społeczeństwo staropolskie. Seria nowa, t. 5: Społeczeństwo a elity, Warszawa 2018, s. 59, 71.

Diariusze sejmu koronacyjnego Zygmunta III Wazy 1587/1588 roku, oprac. I. Kaniewska, Kraków 2016, s. 14.

R. Mazek, Parysów - dobra ziemskie na południowo-wschodnim Mazowszu w XVI-XIX w., Lublin 2015, s. 55-56.

Archiwum Główne Akt Dawnych w Warszawie (dalej: AGAD), Metryka Koronna (dalej: MK) 140, k. 152, 228.

R. Mazek, op.cit., s. 57.

7 Szerzej o tym konflikcie zob. J. Choińska-Mika, Sejmiki mazowieckie w dobie Wazów, Warszawa 1998, s. 36-38.
} 
regalistą. O zaufaniu monarchy świadczy fakt, że Zygmunt III wysłał go jako swego posła do obozu rokoszan pod Sandomierz. W 1611 r. szlachta na sejmiku w Sochaczewie po raz trzeci wybrała go posłem na sejm. Wszedł na nim w skład komisji mającej zająć się sprawami wyznaniowymi w związku z konfliktem religijnym wywołanym zburzeniem zboru kalwińskiego w Wilnie. W tym samym roku awansował na kasztelanię rawską. W tym charakterze przyjechał na sejm zwyczajny w 1613 r., na którym wotował. Ponadto wszedł w skład komisji do sprawy zapłaty żołdu skonfederowanemu wojsku litewskiemu. Na sejm nadzwyczajny w tym samym roku przybył po wotach. Został na nim wyznaczony deputatem do Trybunału Skarbowego w Radomiu. W 1618 r. awansował na wojewodę rawskiego. W tym charakterze uczestniczył kolejno w sejmach z lat 1618, 1619, 1621 (delegowany do komisji ustalającej ceny towarów) oraz 1623, na każdym z nich zabierając głos podczas wotowania.

Jego wystąpienia były przeważnie merytoryczne i cechowały się trzeźwym osądem sytuacji. Przykładowo, na sejmie w 1619 r. przedstawił ciekawe propozycje reform podatkowych z przeznaczeniem na obronę granic, będąc przekonanym o niskiej wartości bojowej pospolitego ruszenia. Mimo że był katolikiem, nie wahał się wysunąć pomysłu opodatkowania duchowieństwa, proponował również pogłówne uzależnione od stopnia zamożności. Na sejmy w latach 1624 i 1627 przybył po wotach. Na tym ostatnim ponownie został deputatem do Trybunału Skarbowego w Radomiu ${ }^{8}$. Z dniem 15 II 1628 r. otrzymał nominację na wojewodę łęczyckiego. W tym samym roku przyjechał po wotach na sejm, gdzie ponownie został wyznaczony w skład deputacji do Trybunału Skarbowego. Był obecny również na dwóch sejmach w 1629 r., choć nie zabierał na nich głosu. Aktywnie uczestniczył za to w obradach w 1631 r. ' Zabierał głos w kwestii reformy elekcji, opowiadając się za powołaniem komisji, która zajęłaby się wypracowaniem odpowiednich rozwiązań w tym zakresie ${ }^{10}$. Został także na tym sejmie wyznaczony w skład komisji do compositio inter status i po raz kolejny do Trybunału Skarbowego. Na ostatni sejm za Zygmunta III w 1632 r. przybył po wotach.

Dużą aktywność przejawiał w czasie bezkrólewia po śmierci pierwszego Wazy ${ }^{11}$. W dniu 2 V 1632 r. był obecny na tajnej naradzie senatorów pod przewodnictwem prymasa, podczas której debatowano m.in. nad terminem zwołania konwokacji, a także zapewnieniem bezpieczeństwa państwa w czasie interregnum. Na sejmie konwokacyjnym kilkakrotnie zabierał głos, przedstawiając konkretne propozycje. Został na nim deputatem do „roztrząsania egzorbitancji”, będąc zresztą jednym z inicjatorów powołania w tym celu specjalnej komisji ${ }^{12}$.

\footnotetext{
8 Volumina Constitutionum, t. 3: 1611-1640, vol. 2: 1627-1640 (dalej: VC, t. 3, vol. 2), do druku przygotowali S. Grodziski, M. Kwiecień, A. Karabowicz, przedm. W. Uruszczak, Warszawa 2013, s. 13, 37.

9 A. Kersten, Hieronim Radziejowski. Studium władzy i opozycji, Warszawa 1988, s. 20-21; M. Kobierecki, op. cit., s. 80, 82 (omyłkowo podaje, że nie było go na sejmie nadzwyczajnym w 1613 r.); MK 155, k. 67v; W. Kłaczewski, Radziejowski Stanisław z Radziejowic h. Junosza (ok. 1575-1637), w: PSB, t. 30, Wrocław 1987, s. 80 autor nie wspomina o jego obecności na sejmie zwyczajnym w 1613 r.; J. Seredyka, Senatorowie Rzeczypospolitej na sejmach Zygmunta III Wazy (1587-1632), w: idem, Rozprawy z dziejów XVI i XVII wieku, Poznań 2003, s. 183; VC, t. 3, vol. 2, s. 103.

10 J. Seredyka, Rzeczpospolita w ostatnich latach panowania Zygmunta III. Zarys wewnętrznych dziejów politycznych (1629-1632), Opole 1978, s. 110.

11 Archiwum Państwowe w Gdańsku (dalej: AP Gdańsk), Recesy stanów zachodniopruskich, sygn. 300/29/111, k. 88

12 W. Kaczorowski, Sejmy konwokacyjny i elekcyjny w okresie bezkrólewia 1632r., Opole 1986, s. 31, 38, 133; A.S. Radziwiłł, Pamiętnik o dziejach w Polsce, tłum. i oprac. A. Przyboś, R. Żelewski, Warszawa 1980, t. 1, s. 113, $122,163$.
} 
Podpisał elekcję Władysława IV z zastrzeżeniem zachowania praw Kościoła katolickiego ${ }^{13}$. Był obecny na sejmie koronacyjnym i uroczystościach pogrzebowych Zygmunta III, w trakcie których niósł koronę Szwecji ${ }^{14}$. Po wotach przybywał na sejmy nadzwyczajne w latach 1634 i 1635. Ostatnimi przejawami jego działalności parlamentarnej były dwa sejmy w $1637 \mathrm{r}$. Na pierwszym sejmie w tym roku wszedł w skład komisji do namówienia obrony, a także deputacji wysłanej przez króla do izby poselskiej. Z kolei na sejmie nadzwyczajnym po raz ostatni został wyznaczony deputatem do Trybunału Skarbowego w Radomiu ${ }^{15}$. Stanisław Radziejowski zmarł w grudniu $1637 \mathrm{r}$.

Następcą Radziejowskiego na kasztelanii rawskiej był Filip Wołucki. Rodzina Wołuckich h. Rawicz wzięła nazwisko od wsi Wołucza leżącej nieopodal Rawy. Filip był synem Jana, podsędka rawskiego, i nieznanej z imienia Ołtarzewskiej h. Lis ${ }^{16}$. Karierę zaczynał jako chorąży rawski. Następnie sprawował urząd starosty rawskiego (1613-1622). Senatorem został w 1619 r., wraz z nominacją na kasztelanię rawską. Z dniem 3 III 1628 r. awansował na urząd wojewody rawskiego ${ }^{17}$. Należał do obowiązkowych senatorów, rzadko uchylających się od udziału w obradach. Za Zygmunta III odnotowano jego obecność na sejmach w latach: $1620,1623,1624,1625$ (wotował), dwóch sejmach w 1626 r. (na obu zabierał głos), 1627, 1628 (wotował), dwóch sejmach w 1629 r., 1631 i ostatnim sejmie za pierwszego Wazy w 1632 r. ${ }^{18}$

Na sejmach kilkakrotnie wyznaczano Wołuckiego deputatem do Trybunału Skarbowego w Radomiu. Znany był z tego, że swoimi wystąpieniami na forum parlamentu potrafił rozbawić pozostałych uczestników obrad do łez. „Wyrywa się - zanotował na sejmie elekcyjnym w 1632 r. kanclerz Radziwiłł - ze śmiechu godną mową wojewoda rawski Wołucki, prostak, ale gorliwy katolik, długo skarżąc się na to, że nie tylko heretycy, ale i katolicy napadali na stan duchowny jakby na samego Boga, a przecież i On, i najświętsza Panna nas zawsze, osobliwie przeciw Turkom broniła, a przez kogo, jeśli nie przez malutkie chłopiątko, pana wojewodę ruskiego [Stanisława Lubomirskiego - MB.], to się stało; i na tym skończył. Wojewoda czerwony od wstydu milczał, lecz wielki śmiech poszedł po polu"19. Był obecny na sejmie koronacyjnym Władysława IV, na którym zabierał głos ${ }^{20}$. Za drugiego Wazy pojawił się jeszcze na kilku sejmach. Na sejmie nadzwyczajnym w 1634 r. wotował i wszedł w skład rady wojennej. Przybył także na dwa sejmy w 1635 r. (wotując na drugim,

13 VC, t. 3, vol. 2, s. 183.

14 W. Kłaczewski, op. cit., s. 80.

15 R. Kołodziej, Pierwszy sejm z 1637 roku, Toruń 2004, s. 275; P. Paradowski, W obliczu „nagłych potrzeb” Rzeczypospolitej. Sejmy ekstraordynaryjne za panowania Władysława IV Wazy, Toruń 2005, s. 238; A. S. Radziwiłł, Pamiętnik..., t. 1, s. 427, 438; t. 2, s. 13, 20, 24.

16 Szerzej o Wołuckich zob. E. Opaliński, Woluccy w stużbie Rzeczypospolitej i Kościoła, w: „, Gorliwość o dom Twój pożera mnie" (Ps 69,10) - kościót pw. Niepokalanego Poczęcia Najświętszej Maryi Panny i kolegium jezuickie w Rawie Mazowieckiej-powstanie i rozwój. Materiały z sesji naukowej-Rawa Mazowiecka 1 czerwca 2019 r., red. M. Broniarczyk, „Notatnik Rawski”, nr 20/2019, s. 17-28. Por. H. D. Wojtyska, Kolegium jezuickie-pierwsza szkoła średnia w Rawie (1620-1773), w: Siedem wieków szkolnictwa w Rawie Mazowieckiej, red. E. Walczuk, Łódź 2010, s. 31-34.

17 MK 176, k. 240.

18 BJ 102, s. 607; BK 289, s. 677; J. Seredyka, Senatorowie Rzeczypospolitej..., s. 216.

19 A.S. Radziwiłl, Pamiętnik..., t. 1, s. 213.

20 Znalazł się także w składzie deputacji senatorskiej, wysłanej przez Władysława IV do izby poselskiej z prośbą o uposażenie jego braci, królewiczów Karola Ferdynanda, Jana Kazimierza i Aleksandra. J. Sobieski, Diariusz sejmu koronacyjnego w Krakowie w 1633 roku, oprac. W. Kaczorowski, J. Dorobisz, Z. Szczerbik, Opole 2008, s. 272-273. 
nadzwyczajnym). Po 1635 roku, jak się zdaje, nie przyjeżdżał już na sejmy ${ }^{21}$. Mimo to jako wieloletni uczestnik komisji skarbowych jeszcze kilka razy był wyznaczany deputatem do Trybunału Skarbowego w Radomiu ${ }^{22}$. Zmarł w 1642 roku.

W omawianym okresie dwóch swoich przedstawicieli w senatorskiej elicie województwa rawskiego mieli Pilchtowie h. Półkozic. Konstanty Plichta był synem Abrahama, kasztelana sochaczewskiego, i Jadwigi z Chądzyńskich. Głównym czynnikiem karierotwórczym były w jego przypadku związki z dworem królewskim. Był m.in. marszałkiem dworu królewicza Władysława ${ }^{23}$. W 1606 roku został senatorem za sprawą nominacji na kasztelanię sochaczewską. Należał do aktywnych senatorów. Wziął udział w sejmach: 1607, 1609, 1611, dwóch w 1613, 1615, 1616, 1620, 1623 i pierwszym sejmie w 1626 r., na większości z nich zabierając głos. W $1630 \mathrm{r}$. awansował na urząd wojewody mazowieckiego, lecz sprawował go krótko, gdyż zmarł już w $1631 \mathrm{r}^{24}$

Do obowiązkowych senatorów, żywo zainteresowanych sprawami publicznymi, należał również bratanek Konstantego - Walenty Plichta, syn Jana, podczaszego rawskiego, i Barbary z Odrzywolskich. Zaczynał od urzędu wojskiego rawskiego. W 1622 r. awansował na podkomorzego rawskiego ${ }^{25}$. Świadczyło to z jednej strony o popularności wśród szlachty, skoro wysunęła go jako jednego z kandydatów do tego elekcyjnego urzędu, z drugiej zaś o zaufaniu króla, który to właśnie jego kandydaturę zatwierdził. Nominację na urząd kasztelana rawskiego otrzymał na sejmie zwyczajnym w 1629 roku. Uczestniczył w obradach ośmiu sejmów za dwóch pierwszych Wazów: drugim sejmie w 1629 r., w 1631, w sejmach konwokacyjnym i elekcyjnym w 1632 r., koronacyjnym w 1633 r., dwóch sejmach w 1635 r. oraz zwyczajnym w $1638 \mathrm{r}$. Na sejmach był wielokrotnie delegowany do udziału w różnego rodzaju komisjach i deputacjach. Był m.in. deputatem do kwarty, a także rady wojennej. Ponadto kilkakrotnie delegowany do Trybunału Skarbowego w Radomiu, zrazu jako deputat z województwa rawskiego $(1626,1627,1629,1631)$, a następnie z senatu $(1633,1637,1638)^{26}$. Brał także udział w tajnych radach senatu. Zmarł w 1639 roku $^{27}$.

Kolejnych dwóch senatorów rawskich, których działalność warto w tym miejscu omówić szerzej, pochodziło z rodziny Lipskich h. Łada ${ }^{28}$. Byli oni braćmi. Starszym z braci był Franciszek Feliks Lipski. Po raz pierwszy na forum publicznym odnotowano go na sejmiku sochaczewskim w dniu 11 XII 1618 r., już wówczas z tytułem podsędka sochaczewskiego ${ }^{29}$.

21 Por. A. Korytko, op.cit., s. 443; L.A. Wierzbicki, op.cit., s. 172.

22 Miało to miejsce na sejmach: nadzwyczajnym w 1637 r. oraz zwyczajnych w 1638 i 1640 r. VC, t. 3, vol. 2, s. $303,323,359$.

23 S. Kobierzycki, Historia Władysława królewicza polskiego i szwedzkiego, wyd. J. Byliński, W. Kaczorowski, thum. M. Krajewski, Wrocław 2005, s. 215, 218, 222, 236, 246, 257, 322.

24 J. Choińska-Mika, J. Dzięgielewski, Plichta Konstanty h. Półkozic, w: PSB, t. 26, Kraków-Wrocław 1981, s. $736-737$.

25 J. Dzięgielewski, Życie polityczne na Mazowszu od schyłku XV do połowy XVII wieku, w: Dzieje Mazowsza lata 1527-1794, t. 2, red. J. Tyszkiewicz, Pułtusk 2015, s. 97-98; Lauda rawskie..., s. 303.

26 E. Kwiecień, D. Kupisz, Deputaci Trybunału Skarbowego Koronnego, w: Trybunat Skarbowy Koronny w Radomiu 1613-1763, red. D. Kupisz, Radom 2013, s. 88.

27 J. Choińska-Mika, J. Dzięgielewski, Plichta Walenty..., s. 738; A. Korytko, op.cit., s. 440; L.A. Wierzbicki, op.cit., s. 125.

28 Na temat tej rodziny zob.: M. Broniarczyk, Kilka uwag..., s. 599-607; P. Anuszczyk, Rody rawskie. Lipscy na Lipiu i Krzemienicy herbu Łada, „Notatnik Rawski”, 2006, nr 10, s. 21-31; D. Kępa, Genealogiczne uzupetnienie rodu Lipskich herbu Łada, „Notatnik Rawski”, 2008, nr 11/12, s. 5-14.

29 AGAD, Riksarkivet Extranea IX Polen, vol. 109, niepag. 
W kolejnych latach awansował na urzędy sędziego ziemskiego (1621-1623) i podkomorzego sochaczewskiego (od 1623 r.) ( $^{30}$. Musiał zatem cieszyć się uznaniem miejscowej szlachty. W tym czasie był bliżej związany z sejmikiem sochaczewskim. Jako jego przedstawiciel został też po raz pierwszy obdarzony mandatem poselskim na sejm w 1624 r. ${ }^{31}$ Swój pierwszy urząd senatorski, kasztelanię sochaczewską, otrzymał zapewne przed sejmem 1631 r., gdyż w tym właśnie charakterze był obecny na obradach. Został też na nim wyznaczony deputatem do kwarty ${ }^{32}$. Był obecny na sejmie konwokacyjnym po śmierci Zygmunta III, gdzie został wyznaczony do asysty przy ciałach króla i królowej oraz złożył podpis pod aktem pacta conventa z wyłączeniem artykułu o dysydentach. Był następnie na elekcji Władysława IV wśród elektorów z ziemi sochaczewskiej ${ }^{33}$.

Jako senator dwukrotnie wziął udział w obradach. Poza tym na kolejnych sejmach był wyznaczany do różnego rodzaju komisji i deputacji. Uczestniczył w sejmach zwyczajnych: 1635 (wotował, deputat do Trybunału Skarbowego) 34 i 1637 (wotował). Ponadto na dwóch innych sejmach, choć nie był obecny, to jednak wyznaczano go do pełnienia różnych funkcji. Na sejmie koronacyjnym 1633 został deputatem do Trybunału Skarbowego w Radomiu. Z kolei z sejmu nadzwyczajnego 1635 r. wyznaczono go jednym z lustratorów do królewszczyzn Mazowsza i Podlasia ${ }^{35}$. Niewiele wiadomo o jego wypowiedziach w trakcie wotowania. Zapewne jednak były podobne do tej regalistycznej z pierwszego sejmu 1637 r., gdzie podnosił zasługi królewskie i zobowiązywał się popierać wszystkie postulaty, na które będzie zgoda na sejmie ${ }^{36}$. W 1639 r. awansował na kasztelanię rawską ${ }^{37}$. Zmarł w 1643 r.

Brat Franciszka Feliksa, Kacper Zygmunt Lipski, zaczął karierę od godności chorążego sochaczewskiego, którą uzyskał w $1625 \mathrm{r}^{38} \mathrm{Z}$ sejmiku sochaczewskiego posłował na sejm konwokacyjny 1632 r. Elekcję Władysława IV podpisał z ziemią sochaczewską. Ten sam sejmik ponownie obdarzył go zaufaniem, wysyłając na sejm koronacyjny w $1633 \mathrm{r} .{ }^{39} \mathrm{~W} 1639 \mathrm{r}$., po awansie brata Franciszka Feliksa na kasztelanię rawską, otrzymał po nim kasztelanię sochaczewską. Po śmierci brata w 1643 r. przejął po nim z kolei wielkosenatorskie krzesło kasztelana rawskiego. Jeszcze jako kasztelan sochaczewski, na sejmie w 1640 r., został wyznaczony deputatem do Trybunału Skarbowego w Radomiu, choć nie był na nim obecny ${ }^{40}$.

30 Nominację na podkomorstwo otrzymał w dniu 30 VIII 1623 r. po śmierci N. N. Tarnowskiego. MK 169, k. 247-248. Por. M. Broniarczyk, Wykształcenie świeckich senatorów w Koronie za Władysława IV, „Kwartalnik Historyczny", 109/2012, 2, s. 287.

31 B. Oss. 1926/II, k. 56; J. Choińska-Mika, Sejmiki mazowieckie..., s. 183.

32 MK 178, k. 266v; Volumina Legum, wyd. J. Ohryzko, Petersburg 1859 (dalej: VL), t. 3, s. 338.

33 AP Gdańsk 300/29/112, k. 540; B. Czart. 373, s. 158; W. Kaczorowski, P. Dydyński, Reprezentacja Mazowsza i Podlasia wśród elektorów Władysława IV Wazy, „Studia z Dziejów Państwa i Prawa Polskiego”, 9/2006, s. 283; M. Kobierecki, op. cit., s. 86 przyp. 60 i 64.

34 VL, t. 3, s. 409.

35 Akta do dziejów Polski na morzu, t. 7, 1632-1648, cz. 1, wyd. W. Czapliński, teksty niemieckie opracował językowo B. Janik, Gdańsk 1951, s. 22, 155; AP Gdańsk 300/29/115, k. 97; A. Korytko, op. cit., s. 439; VL, t. 3, s. 409, 425.

36 R. Kołodziej, op. cit., s. 136.

37 B. Oss. 5561/II, s. 412.

38 MK 172, k. 119.

39 J. Choińska-Mika, Sejmiki mazowieckie..., s. 184; J. Dzięgielewski, Izba poselska w systemie władzy w Rzeczypospolitej w czasach Władysława IV, Warszawa 1992, s. 171; W. Kaczorowski, P. Dydyński, op. cit., s. 288.

40 VL, t. 3, s. 470. W innym miejscu: M. Broniarczyk, Kilka uwag..., s. 603, omyłkowo podałem, że był obecny na sejmie $1640 \mathrm{r}$. 
Był obecny na sejmie w 1643 r. i został na nim wyznaczony deputatem do Rawy „na odbieranie kwarty"41. Zjawił się także na sejmie 1646 r. $^{42}$ Elekcję Jana Kazimierza podpisał z ziemią rawską. Na sejmie koronacyjnym w 1649 r. został wyznaczony jednym z senatorów rezydentów ${ }^{43}$. Za panowania Jana Kazimierza nie przyjeżdżał już na sejmy, choć zaznaczył swą obecność w inny sposób, biorąc udział w 1651 r. w bitwie pod Beresteczkiem. Zdążył jeszcze awansować na najwyższy urząd w rodzimym rawskim, zostając w 1654 r., po śmierci Łukasza Opalińskiego, miejscowym wojewodą ${ }^{44}$. Na tym urzędzie zmarł przed 3 IV $1656 \mathrm{r}$.

Ostatnim z senatorów rawskich, którego sylwetkę warto w tym miejscu przybliżyć, jest Mikołaj Łajszczewski (Łaściszewski) h. Ślepowron. Był on synem Feliksa, komornika granicznego sochaczewskiego, i Anny z Błędowskich. Mikołaj wiele zawdzięczał protekcji arcybiskupa gnieźnieńskiego Macieja Łubieńskiego. Jako marszałek jego dworu i jeden z egzekutorów testamentu z pewnością zaliczał się do osób, które Łubieński miał na uwadze, promując jego karierę polityczną. Jeszcze za Zygmunta III dostał się do kancelarii królewskiej i pełnił funkcję sekretarza ${ }^{45}$. Cieszył się także popularnością i zaufaniem wśród szlachty, która sześciokrotnie powierzała mu mandat posła na sejmy z sejmików w Rawie i Sochaczewie. Senatorem został w 1643 r., kiedy to otrzymał nominację na kasztelanię sochaczewską. Po wejściu do izby wyższej staropolskiego parlamentu należał do bardzo obowiązkowych senatorów. Wziął udział w większości sejmów, które odbyły się w czasie, kiedy pełnił swój urząd. Za panowania Władysława IV zanotował swoją obecność na sejmach w latach: 1643 (wotował), 1645 i 1646 (wotował). Trudno powiedzieć, czy był obecny na sejmie w $1647 \mathrm{r}^{46}$ Jest to o tyle prawdopodobne, że został na nim wyznaczony aż do trzech komisji posejmowych, choć sam fakt wyznaczenia do komisji posejmowej nie musi świadczyć o obecności senatora na sejmie ${ }^{47}$. W czasie bezkrólewia po śmierci drugiego Wazy zjawił się na sejmie konwokacyjnym 1648 r. Za panowania Jana Kazimierza był obecny na

\footnotetext{
41 Z pewnością nie był wszak obecny podczas wotowania. B. Czart. 309, s. 547; BK 1829, niepag.; A. Korytko, op. cit., s. 451; VL, t. 4, s. 39.

42 A. Korytko, op. cit., s. 439. Jerzy Wiśniewski w PSB nie wspomina o sejmach 1640 i 1646 r., z kolei S. Hołdys odnotowuje go tylko na tylko na tym drugim. Por. S. Hołdys, Praktyka parlamentarna za panowania Władysława IV Wazy, Wrocław 1991, s. 191; J. Wiśniewski, Lipski Kasper Zygmunt (ok. 1591-ok. 1656), w: PSB, t. 16, Wrocław 1972, s. 437. Jako obecnego już na początku sejmu wspomina go autor diariusza z BJ 49, s. 149, jednak nic więcej nie podaje. Trudno powiedzieć więc, czemu na nim nie wotował, skoro nie wymieniaja go w tym charakterze diariusze A.S. Radziwiłł, Pamiętnik ..., t. 2, s. 507-508; BN BOZ 855, k. 454v-460v; BN BOZ 858, k. 105v; S. Oświęcim, Diariusz 1643-1651, wyd. W. Czermak, Kraków 1907, s. 171-172. Być może z jakichś powodów był zmuszony odjechać tuż po inauguracji obrad lub zachorował. Niewykluczone zresztą, że pomylił się autor diariusza, z rozpędu obok wojewody rawskiego wymieniając także miejscowego kasztelana.

43 J. Wiśniewski, op. cit., s. 437. Por. listę senatorów obecnych na tym sejmie w: S. Ochmann, Sejm koronacyjny Jana Kazimierza w 1649 r., Wrocław 1985, s. 245.

44 BK 991, k. 119v-120.

45 M. Kobierecki powtarza za A. Kerstenem błędną informacją jakoby miał Łajszczewski otrzymać tytuł sekretarza królewskiego dopiero dzięki protekcji H. Radziejowskiego na początku lat 40. Tymczasem najpewniej automatycznie ,przejął” go Władysław po swoim ojcu, gdyż już przed tą datą określany on jest mianem „,sekretarza naszego", np. w 1635 r. w konstytucji sejmowej. A. Kersten, op. cit., s. 64-65; M. Kobierecki, op. cit., s. 84 przyp. 52; VL, t. 3, s. 425.

46 A. Korytko, op. cit., s. 439 - nie znalazł źródeł potwierdzających jego obecność na tym sejmie.

47 VC, t. 4, vol. 1, s. 92, 109, 111.
} 
sejmach: koronacyjnym 1649 r., 1650, dwóch sejmach w 1652 r. (na sejmie nadzwyczajnym wyznaczony deputatem do Rawy) oraz w 1655 r. ${ }^{48}$ Zmarł w 1655 r.

Senatorowie z województwa rawskiego, których życiorysy zaprezentowano powyżej, stanowili niewątpliwie ciekawą galerię postaci. Analiza zbiorowości urzędników zasiadających na tym urzędzie w badanym okresie nasuwa kilka spostrzeżeń.

W omawianym okresie odbyło się 79 sejmów. Wojewodowie rawscy pojawili się na 28 sejmach, zaś kasztelanowie rawscy i sochaczewscy na 25 sejmach. Jedynie kasztelanowie gostynińscy w czasie tych 81 lat pojawili się tylko na 3 sejmach. Co ciekawe, każda z tych obecności miała miejsce za panowania poszczególnych monarchów z dynastii Wazów. I tak: za panowania Zygmunta III Wazy na sejmie z 1597 r. pojawił się Jan Stępowski (Stempowski), w czasach Władysława IV na pierwszy sejm w 1637 r. przybył Adam Noskowski, zaś za Jana Kazimierza na drugim sejmie w 1652 r. odnotował swoją obecność Marcin Sadowski. Warto dodać, że żaden z nich nie wotował na tych sejmach. Niewątpliwie więc kasztelanowie gostynińscy stanowili najmniej zaangażowaną politycznie grupę senatorów z województwa rawskiego. Wynikało to z różnych względów. Wielu z nich po prostu zaliczało się do ludzi biernych, nie interesujących się polityką. Jak można przypuszczać, w niektórych przypadkach uzyskali tę kasztelanię mniejszą bardziej dzięki protekcji niż zaangażowaniu politycznemu. Jako przykład można podać chociażby Piotra Tarnowskiego h. Rolicz, z „biskupiego rodu”, krewnego prymasa Jana Tarnowskiego, szwagra Marcina Krasickiego, wojewody podolskiego. Poza tym rodzina ta była bardziej związana z województwem łęczyckim. Jako inny przykład można podać Michała z Warzymowa Sokołowskiego h. Pomian, związanego bardziej z Kujawami i Wielkopolską.

Jest to kolejna rzecz charakterystyczna. Do najbardziej aktywnych politycznie senatorów z Rawskiego należały te osoby, których rodziny wywodziły się z województwa rawskiego. Przedstawiciele chociażby rodzin Lipskich czy Plichtów byli miejscową szlachtą osiadłą tu od dawna. Nie dziwi więc, że, aspirując do najwyższych godności w rodzimym województwie, starali się zabiegać o względy braci herbowej i popularność, chociażby na sejmikach. W zdecydowanej większości senatorowie, których życiorysy zaprezentowano powyżej, już w okresie przed awansem senatorskim należeli do osób znanych i popularnych na lokalnym forum publicznym. Wielu z nich regularnie posłowało na sejmy, bądź też pełniło elekcyjne urzędy sądowe ziemskie. Trzeba też pamiętać o bezpośrednich związkach z dworem poprzez pełnienie funkcji sekretarzy i dworzan królewskich. Co również charakterystyczne dla biografii senatorów przedstawionych powyżej, to umiejętne łączenie kilku dróg robienia kariery. Dobrym przykładem jest tu przebieg kariery Mikołaja Łajszczewskiego. Na tle elity w skali województwa, za jaką w czasach Wazów można uznać Lipskich czy Plichtów, nie mówiąc o Radziejowskich, którzy utrzymali status wielkosenatorski do końca XVII wieku, familia Łajszczewskich jawi się jako uboga. Mimo to Mikołajowi udało się zrobić największą karierę w dziejach rodziny i zostać senatorem. Wynikało to niewątpliwie z jego osobistych zdolności, ale także umiejętnego łączenia różnych modeli robienia kariery. Była to zarówno protekcja osoby wpływowej (prymasa Macieja Łubieńskiego), uznanie wśród szlachty mierzone wielokrotnym obdarzaniem go mandatem posła na sejmy (6 posłowań),

48 J. S. Dąbrowski, Senat koronny. Stan sejmujący w czasach Jana Kazimierza, Kraków 2000, s. 197; S. Ochmann-Staniszewska, Staniszewski Z., Sejm Rzeczypospolitej za panowania Jana Kazimierza Wazy. Prawo - doktryna praktyka, Wrocław 2000, t. 1, s. 111; L. A. Wierzbicki, op.cit., s. 102. Ponadto na sejmie 1649/50 wyznaczony jednym z lustratorów królewszczyzn w Wielkopolsce. VC, t. 4, vol. 1, s. 197, 264. 
jak i bezpośrednie związki z dworem dzięki pełnieniu funkcji sekretarza królewskiego. Awans senatorski będący ukoronowaniem jego kariery dał mu dalsze możliwości realizacji na gruncie politycznym. Również jako senator należał do obowiązkowych urzędników regularnie przyjeżdżających na sejmy i zabierających głos. Nie było to wszak regułą. Niekiedy otrzymanie godności senatorskiej powodowało „spoczęcie na laurach”, co widać - oprócz innych czynników - na przykładzie kasztelanów gostynińskich z omawianego okresu.

Na popularności wśród szlachty zyskanej dzięki posłowaniu na sejmy, a także sprawowaniu elekcyjnych urzędów sądowych ziemskich, bazowali także przedstawiciele rodziny Lipskich. Poza tym mieli dodatkowy atut w postaci protekcji ich rodzonego brata - Jana, arcybiskupa gnieźnieńskiego ${ }^{49}$. Zwłaszcza w czasach Zygmunta III i Władysława IV na urzędach senatorskich w województwie rawskim, z wyjątkiem kasztelanii gostynińskiej, znaleźć można całkiem sporą grupę osób zaangażowanych politycznie i żywo zainteresowanych czynnym udziałem w życiu publicznym zarówno na forum lokalnym - sejmikowym, jak ogólnopolskim - sejmowym.

Bardzo charakterystyczny dla zbiorowości senatorów z województwa rawskiego jest fakt, iż zdecydowana większość z nich była regalistami. Doskonale widać to na przykładzie okresów napięć politycznych, jakimi były rokosze. W dobie rokoszu Zebrzydowskiego jedynie wojewoda rawski Zygmunt Grudziński sympatyzował z tym ruchem ${ }^{50}$. Warto dodać, że był protestantem, co też wyróżnia go na tle całej badanej zbiorowości, w której zdecydowaną większość stanowili katolicy. W czasie rokoszu Lubomirskiego nastroje wśród szlachty województwa rawskiego były bardziej spolaryzowane. Charakterystyczne jednak, że dotyczyło to urzędników niższego szczebla. Przykładowo, ówczesny chorąży rawski Piotr Śladkowski, późniejszy kasztelan sochaczewski, walczył po stronie Lubomirskiego jako rotmistrz chorągwi pancernej i należał do jego aktywnych zwolenników ${ }^{51}$. W przypadku senatorów pełniących wówczas urzędy w Rawskiem, sytuacja wyglądała inaczej. Jeśli chodzi o wojewodę rawskiego Jana Olbrachta Lipskiego można przypuszczać, że silne regalistyczne tradycje kultywowane w tej rodzinie zostały podtrzymane. Niewiele zresztą wiadomo na temat jego działalności w tym okresie, podobnie jak Wojciecha Mokronowskiego, kasztelana rawskiego, i Jana Szamowskiego, kasztelana gostynińskiego. W każdym razie nie widać ich wśród aktywnych działaczy żadnej ze stron. Jedynym senatorem z województwa, który zaznaczył w tym czasie swoją obecność, był Marcin Jarzyna, kasztelan sochaczewski, którego nazwisko widnieje wśród sygnatariuszy układu w Łęgonicach ${ }^{52}$.

\footnotetext{
49 A. Moniuszko, Mazowieckie sądy ziemskie (1588-1648). Organizacja-funkcjonowanie - postepowanie, Warszawa 2013, s. 136.

50 E. Opaliński, Zjazd rokoszowy warszawski w październiku 1607 r., „Kwartalnik Historyczny”, 121/2014, nr 3, s. 535 .

51 Wstę, w: Lauda rawskie..., s. 12.

52 J.Ch. Pasek, Pamiętniki, red. S. Sierpowski, wstęp I. Kraszewski, przyp. W. Czapliński, Wrocław 2010, t. 2, s. 331.
} 


\section{Aneks}

Senatorowie $z$ województwa rawskiego uczestniczący $w$ sejmach za panowania Wazów

Skróty:

A - awans

a. - ante

maz. - mazowieckiego

ob. - obecny na sejmie, nie wotował

raw. - rawskie, rawskiego

$\mathrm{R}$ - rezygnacja z urzędu

$\mathrm{W}$ - wotował

woj. - wojewoda, województwo

zm. - zmarł 


\begin{tabular}{|c|c|c|c|c|}
\hline :్రి & 3 & & & \\
\hline 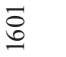 & & & & \\
\hline$\underset{8}{8}$ & & & & \\
\hline$\stackrel{\infty}{n}$ & & & & \\
\hline ถิ & 3 & هं & ஃ் & 8े \\
\hline i̊ & ல் & ல் & & \\
\hline $\begin{array}{l}\approx \\
\stackrel{2}{n}\end{array}$ & 3 & & & \\
\hline ڤิ) & هं & & & \\
\hline مิ & 3 & & & \\
\hline $\begin{array}{l}\bar{\sigma} \\
\text { ڤे } \\
\stackrel{\circ}{-}\end{array}$ & 3 & & & \\
\hline î & 3 & & & \\
\hline$\stackrel{\mathscr{D}}{\stackrel{2}{n}}$ & ல் & ठิ & ல் & \\
\hline $\begin{array}{l}\infty \\
\substack{\infty \\
\infty \\
n \\
n}\end{array}$ & & ஃ் & $\dot{0}$ & \\
\hline 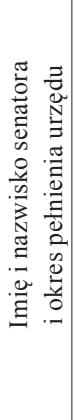 & 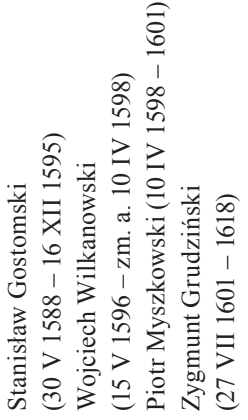 & 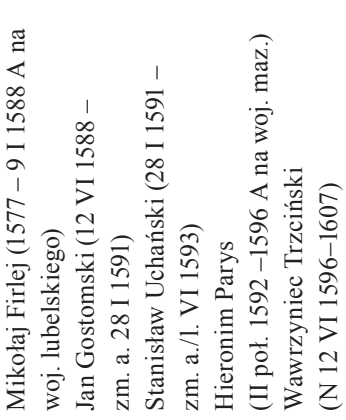 & 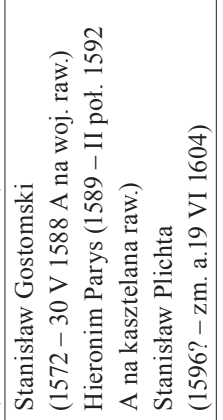 & 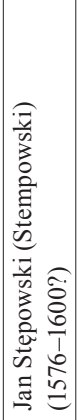 \\
\hline 胥 & 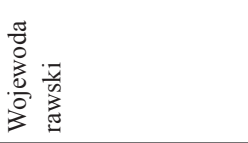 & 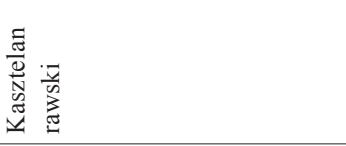 & 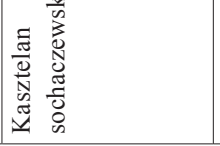 & 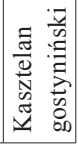 \\
\hline
\end{tabular}




\begin{tabular}{|c|c|c|c|c|}
\hline$\overline{\widehat{\sigma}}$ & 3 & & & \\
\hline હ્ర్రి & & ه் & 8̊ & \\
\hline$\stackrel{\vec{\sigma}}{ }$ & 3 & & & \\
\hline$\stackrel{\infty}{\sigma}$ & 3 & & & \\
\hline$\stackrel{0}{\circ}$ & & & 3 & \\
\hline$\frac{n}{6}$ & & & 3 & \\
\hline 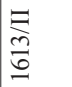 & 3 & ठิ & 3 & \\
\hline 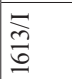 & & 3 & 3 & \\
\hline$\vec{\Xi}$ & & & $\dot{8}$ & \\
\hline : & & & 3 & \\
\hline : & & 3 & 8े & \\
\hline 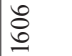 & 3 & & & \\
\hline 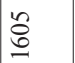 & 3 & & & \\
\hline 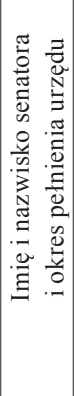 & 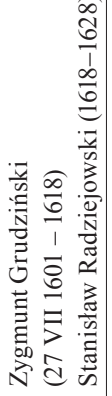 & 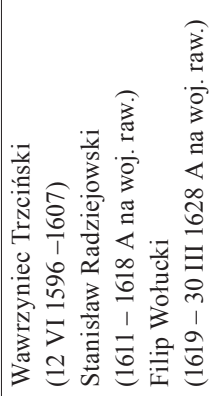 & 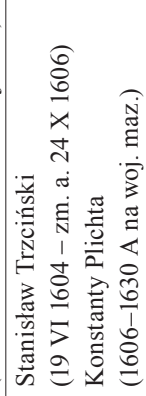 & 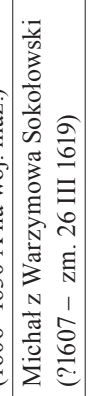 \\
\hline 胥 & 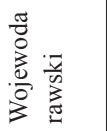 & 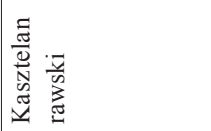 & 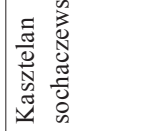 & 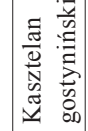 \\
\hline
\end{tabular}

\begin{tabular}{|c|c|c|c|c|}
\hline 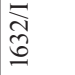 & 8 & & & \\
\hline $\overrightarrow{\hat{\sigma}}$ & هं & 。ं & ه & \\
\hline 离 & ठิ & هं & & \\
\hline 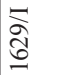 & 8 & $\dot{8}$ & & \\
\hline$\underset{\widetilde{d}}{\stackrel{\infty}{d}}$ & 3 & & & \\
\hline$\widehat{\widehat{్}}$ & ஃ் & هं & & \\
\hline 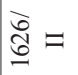 & & 3 & & \\
\hline 矛 & & 3 & 3 & \\
\hline ڤ్రి & & 3 & & \\
\hline$\underset{\mathbb{\sigma}}{\mathbb{J}}$ & 8் & هं & & \\
\hline త్ర్ర & 3 & லे & 3 & \\
\hline 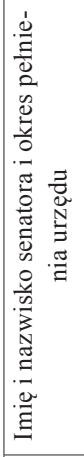 & 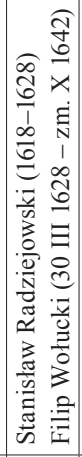 & 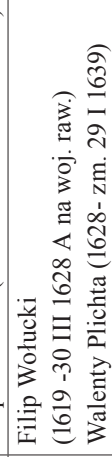 & 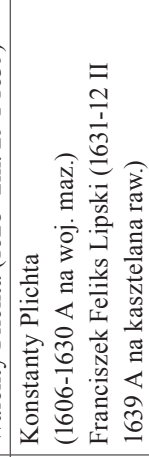 & 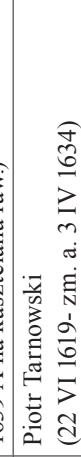 \\
\hline 胥 & 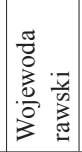 & 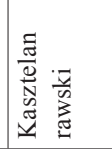 & 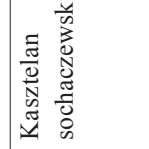 & 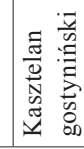 \\
\hline
\end{tabular}




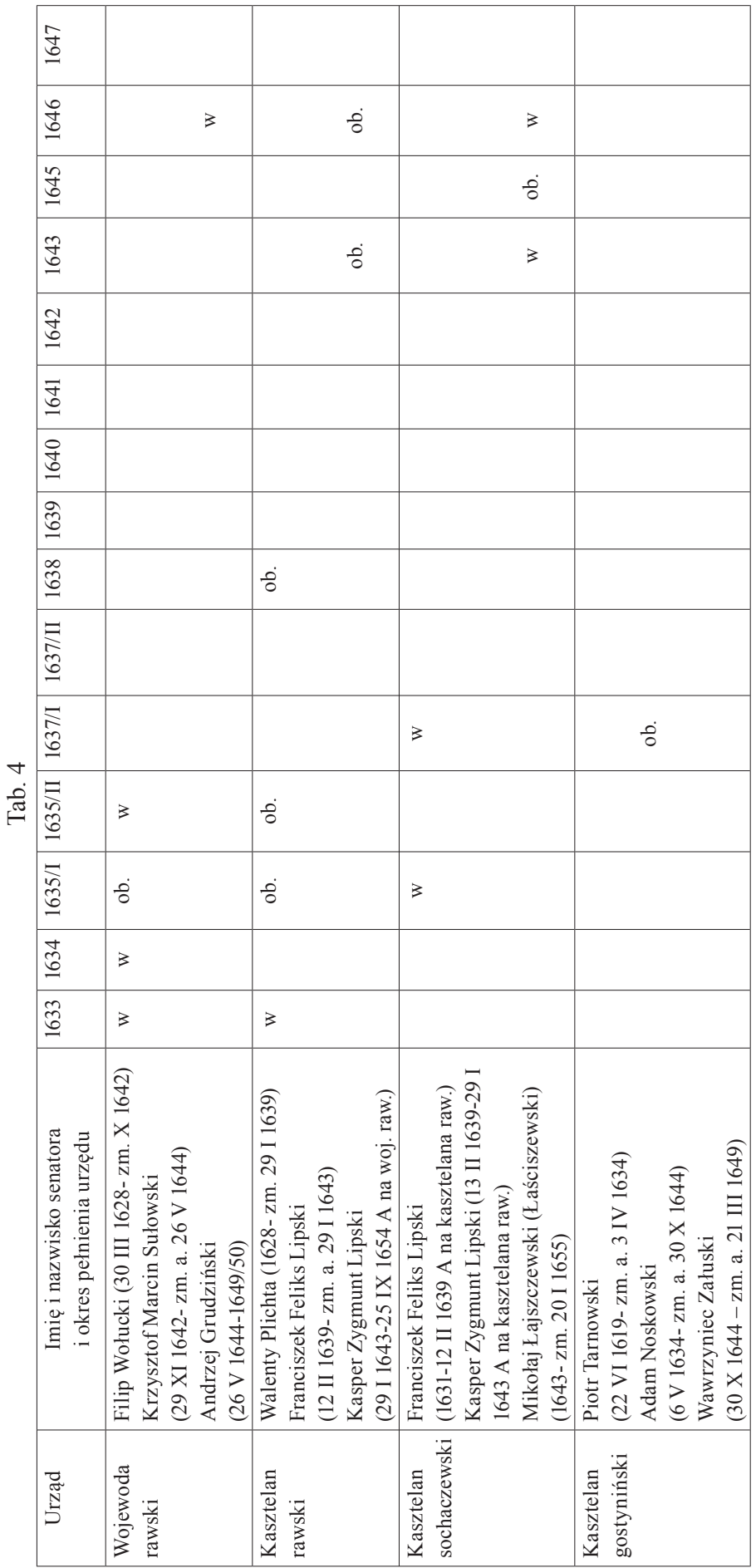




\begin{tabular}{|c|c|c|c|c|}
\hline$\overbrace{0}^{\infty}:=$ & & ठ் & & \\
\hline$\overbrace{0}^{\infty}=$ & & & & \\
\hline 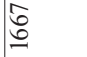 & & ஷ & & \\
\hline$\stackrel{0}{:}=$ & & & & \\
\hline$\overbrace{0}^{\circ}=$ & & & & \\
\hline 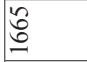 & & & & \\
\hline $\mathbb{d}_{0}^{0}: 3$ & & & 3 & \\
\hline 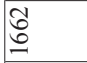 & & ठ் & & \\
\hline $\overrightarrow{0}$ & & & & \\
\hline है & & & & \\
\hline 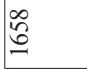 & & & & \\
\hline$\tilde{n}$ & & & 3 & \\
\hline 芯 & & & & \\
\hline 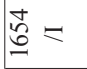 & & & & \\
\hline$\hat{\tilde{b}}$ & & & & \\
\hline$\tilde{\hat{\sigma}}$ & & & ه & ல் \\
\hline$\tilde{\underline{B}}=$ & & & 3 & \\
\hline 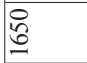 & & & 3 & \\
\hline 宅 & & & & \\
\hline 宊 & & & 3 & \\
\hline 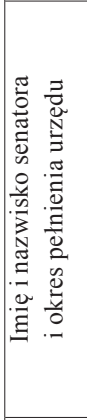 & 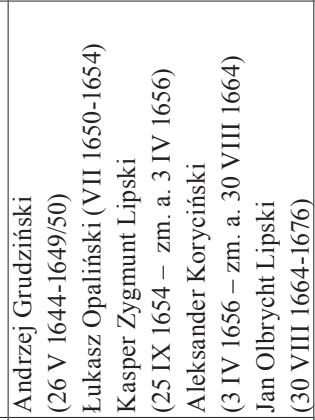 & 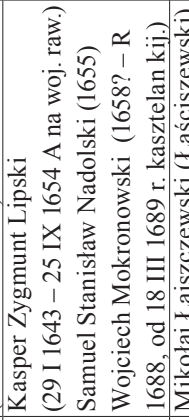 & 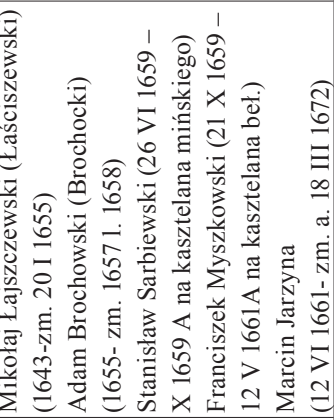 & 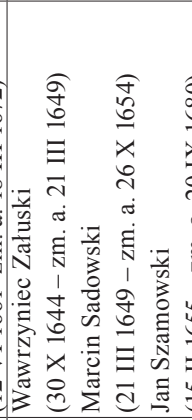 \\
\hline 胥 & 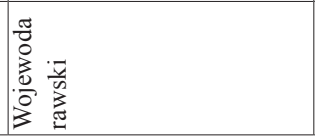 & 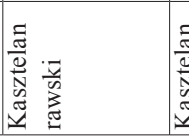 & 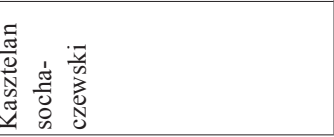 & 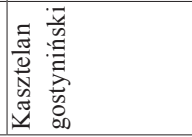 \\
\hline
\end{tabular}




\section{Bibliografia}

\section{Źródła archiwalne}

Archiwum Główne Akt Dawnych w Warszawie:

Metryka Koronna ks. 140, 155, 169, 172, 176, 178.

Riksarkivet Extranea IX Polen, vol. 109 (mikrofilm).

Archiwum Państwowe w Gdańsku (dalej: AP Gdańsk), Recesy stanów zachodniopruskich, sygn. 300/29/111, 112, 115.

Biblioteka Jagiellońska w Krakowie rkps. 49, 102.

Biblioteka Muzeum Narodowego im. Czartoryskich w Krakowie rkps. 309, 373.

Biblioteka Narodowa w Warszawie:

Biblioteka Ordynacji Zamoyskich rkps. 855, 858.

Biblioteka Polskiej Akademii Nauk w Kórniku rkps. 289, 991, 1829.

Biblioteka Zakładu Narodowego im. Ossolińskich we Wrocławiu rkps. 1926/II, 5561/II.

\section{Źródla drukowane}

Akta do dziejów Polski na morzu, t. 7: 1632-1648, cz. 1, wyd. W. Czapliński, teksty niemieckie opracował językowo B. Janik, Gdańsk 1951.

Akta sejmikowe województwa lubelskiego 1572-1632, oprac. H. Gmiterek, Lublin 2016.

Diariusze sejmu koronacyjnego Zygmunta III Wazy 1587/1588 roku, oprac. I. Kaniewska, Kraków 2016.

Kobierzycki S., Historia Władysława królewicza polskiego i szwedzkiego, wyd. J. Byliński, W. Kaczorowski, tłum. M. Krajewski, Wrocław 2005.

Lauda ziemi rawskiej i województwa rawskiego 1583-1793, oprac. M. Bąk, M. Borkowski, K. Chłapowski, A. Haratym, T. Płóciennik, Ł. Przybyłek, E. Walczuk, red. M. Nagielski, Warszawa 2017.

Oświęcim S., Diariusz 1643-1651, wyd. W. Czermak, Kraków 1907.

Pasek J. Ch., Pamiętniki, red. S. Sierpowski, wstęp I. Kraszewski, przyp. W. Czapliński, Wrocław 2010.

Radziwiłł A. S., Pamiętnik o dziejach w Polsce, tłum. i oprac. A. Przyboś, R. Żelewski, Warszawa 1980.

Sobieski J., Diariusz sejmu koronacyjnego w Krakowie w 1633 roku, oprac. W. Kaczorowski, J. Dorobisz, Z. Szczerbik, Opole 2008.

Volumina Constitutionum, t. 3: 1611-1640, vol. 2: 1627-1640, do druku przygotowali S. Grodziski, M. Kwiecień, A. Karabowicz, przedm. W. Uruszczak, Warszawa 2013.

Volumina Legum, wyd. J. Ohryzko, Petersburg 1859, t. 3.

\section{Opracowania}

Anuszczyk P., Rody rawskie. Lipscy na Lipiu i Krzemienicy herbu Łada, „Notatnik Rawski”, 2006, nr 10, s. 21-31.

Broniarczyk M., Kasztelanowie rawscy doby Wazów (1587-1668), [w druku].

Broniarczyk M., Kasztelanowie mniejsi z Wielkopolski, Kujawi Mazowsza w czasach Władystawa IV, praca doktorska napisana pod kierunkiem prof. dr. hab. Edwarda Opalińskiego, Warszawa 2015, maszynopis w Bibliotece IH PAN w Warszawie. 
Broniarczyk M., Kilka uwag o edukacji rawskiej elity politycznej w XVII w. na przykładzie Lipskich h. Łada, w: Najjaśniejsza Rzeczypospolita. Studia ofiarowane Profesorowi Andrzejowi Stroynowskiemu, red. M. Durbas, Częstochowa 2019, s. 599-607.

Broniarczyk M., Wykształcenie świeckich senatorów w Koronie za Władysława IV, „Kwartalnik Historyczny", 109/2012, nr 2, s. 251-303.

Choińska-Mika J., Dzięgielewski J., Plichta Konstanty h. Półkozic, w: Polski Słownik Biograficzny (dalej: PSB), t. 26, Kraków-Wrocław 1981, s. 736-737.

Choińska-Mika J., Sejmiki mazowieckie w dobie Wazów, Warszawa 1998.

Dąbrowski J. S., Senat koronny. Stan sejmujący w czasach Jana Kazimierza, Kraków 2000.

Dzięgielewski J., Izba poselska w systemie władzy w Rzeczypospolitej w czasach Władysława IV, Warszawa 1992.

Dzięgielewski J., Życie polityczne na Mazowszu od schyłku XV do połowy XVII wieku, w: Dzieje Mazowsza lata 1527-1794, t. 2, red. J. Tyszkiewicz, Pułtusk 2015, s. 29-113.

Hołdys S., Praktyka parlamentarna za panowania Władysława IV Wazy, Wrocław 1991.

Kaczorowski W., Dydyński P., Reprezentacja Mazowsza i Podlasia wśród elektorów Władysława IV Wazy, „Studia z Dziejów Państwa i Prawa Polskiego”, 9/2006, s. 273-303.

Kaczorowski W., Sejmy konwokacyjny i elekcyjny w okresie bezkrólewia 1632 r., Opole 1986.

Kersten A., Hieronim Radziejowski. Studium władzy i opozycji, Warszawa 1988.

Kępa D., Genealogiczne uzupetnienie rodu Lipskich herbu Łada, „Notatnik Rawski”, 2008, nr 11/12, s. 5-14.

Kieniewicz L., Senat za Stefana Batorego, Warszawa 2000.

Kłaczewski W., Radziejowski Stanisław z Radziejowic h. Junosza (ok. 1575-1637), w: PSB, t. 30, Wrocław 1987, s. 79-81.

Kobierecki M., Aktywność parlamentarzystów rawskich na sejmach za panowania Wazów 1587-1668, „Przegląd Nauk Historycznych”, 5/2006, nr 1(9), s. 75-107.

Kołodziej R., Pierwszy sejm z 1637 roku, Toruń 2004.

Korytko A., ,Na których opiera się Rzeczpospolita”. Senatorowie koronni za Władysława IV Wazy, Olsztyn 2015.

Kwiecień E., Kupisz D., Deputaci Trybunatu Skarbowego Koronnego, w: Trybunat Skarbowy Koronny w Radomiu 1613-1763, red. D. Kupisz, Radom 2013, s. 79-94.

Lepszy K., Gostomski Stanisław z Leżenic, w: PSB, t. 8, Wrocław 1959-1960, s. 367-369.

Mazek R., Parysów - dobra ziemskie na południowo-wschodnim Mazowszu w XVI-XIX w., Lublin 2015.

Moniuszko A., Mazowieckie sady ziemskie (1588-1648). Organizacja - funkcjonowanie postępowanie, Warszawa 2013.

Ochmann S., Sejm koronacyjny Jana Kazimierza w 1649 r., Wrocław 1985.

Ochmann-Staniszewska S., Staniszewski Z., Sejm Rzeczypospolitej za panowania Jana Kazimierza Wazy. Prawo - doktryna - praktyka, Wrocław 2000.

Opaliński E., Woluccy w stużbie Rzeczypospolitej i Kościoła, w: „,Gorliwość o dom Twój pożera mnie" (Ps 69,10) - kościót pw. Niepokalanego Poczęcia Najświętszej Maryi Panny i kolegium jezuickie w Rawie Mazowieckiej - powstanie i rozwój. Materiały z sesji naukowej-Rawa Mazowiecka 1 czerwca 2019 r., red. M. Broniarczyk, „Notatnik Rawski”, 20/2019, s. 17-28.

Opaliński E., Zjazd rokoszowy warszawski w październiku 1607 r., „Kwartalnik Historyczny”, 121/2014, nr 3, s. 521-539. 
Paradowski P., W obliczu „,nagtych potrzeb” Rzeczypospolitej. Sejmy ekstraordynaryjne za panowania Władysława IV Wazy, Torun 2005.

Seredyka J., Rzeczpospolita w ostatnich latach panowania Zygmunta III. Zarys wewnętrznych dziejów politycznych (1629-1632), Opole 1978.

Seredyka J., Senatorowie Rzeczypospolitej na sejmach Zygmunta III Wazy (1587-1632), w: idem, Rozprawy z dziejów XVI i XVII wieku, Poznań 2003, s. 155-237.

Wierzbicki L. A., Senatorowie koronni na sejmach Rzeczypospolitej w XVII wieku, Warszawa 2017.

Wiśniewski J., Lipski Kasper Zygmunt (ok. 1591-ok. 1656), w: PSB, t. 16, Wrocław 1972, s. 436-437.

Wojtyska H. D., Kolegium jezuickie - pierwsza szkoła średnia w Rawie (1620-1773), w: Siedem wieków szkolnictwa w Rawie Mazowieckiej, red. E. Walczuk, Łódź 2010, s. 29-60.

Wroniszewski Ł., Elity szlacheckie na sejmie - frekwencja senatorska na sejmach Stefana Batorego (1576-1586), w: Społeczeństwo staropolskie. Seria nowa, t. 5: Społeczeństwo a elity, Warszawa 2018, s. 37-86. 